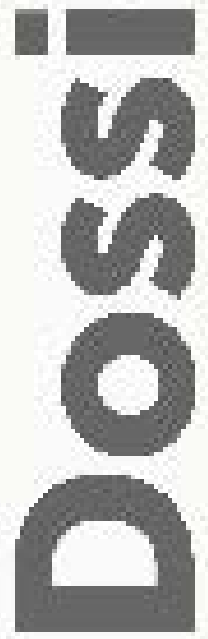

\title{
Por uma arqueologia dos vestígios funerários do passado: contribuições, práticas e caminhos possiviveis
}

\author{
Towards an archaeology of the funerary remains \\ of the past:
}

\section{RESUMO}

O presente artigo oferece uma reflexão crítica a respeito da morte como campo profícuo para o estudo do passado, em especial, a partir das contribuições advindas da Arqueologia Funerária. Ele sintetiza algumas das principais contribuições intelectuais provenientes do antiquarismo, da arqueologia processual e pós-processual para o entendimento das práticas mortuárias e, não obstante, aponta ao leitor maneiras de incorporar tais contribuições para melhor entendimento da morte e enterramentos em contextos passados. Afinal, o que a Arqueologia Funerária tem a oferecer à História, e por que ela é apenas ainda perifericamente incorporada ao debate? Traçando um conjunto de propostas fluidas e colaborativas entre o ofício arqueológico e historiográfico, o artigo mapeia um caminho frutífero a ser percorrido, em um ensaio sobre os potenciais do estudo do passado por intermédio da materialidade deixada pelos vestígios funerários.

Palavras-Chave: Arqueologia Funerária - Historiografia - Diálogos entre História - Arqueologia

\begin{abstract}
This paper offers a critical look on death, highlighting the richness of its potential as a field for the study of the past, particularly in terms of the contributions of Funerary Archaeology. The article offers a synthesis of some of the most important intellectual contributions offered by Antiquarianism, Processual, and Post-Processual Archaeology to the study of mortuary practices, with the aim of presenting to the reader a variety of ways in which these contributions might help us today to think about death and burials in multiple past contexts. How can Funerary Archaeology enrich History, and why is it still only marginally present in our discussions of the past? In order to answer some of these questions, the article will also contain suggestions of areas for action, showing a possible path taken for those who seek to study the past through the funerary vestiges it has left us.
\end{abstract}

Keywords: Funeral Archeology - Historiography - Dialogues between History - Archeology

* Doutor em História pelo Programa de Pós-Graduação em História da Universidade Federal Fluminense (PPGH-UFF), com "periodo sanduíche" de um ano na Universidade de Manchester (Reino Unido). Atualmente realiza pós-doutorado com bolsa no Programa de Pós-Graduação em História Comparada, da Universidade Federal do Rio de Janeiro (PPGHC-UFRJ). Pesquisador e membro do NEREIDA (Núcleo de Estudos de Representações e de Imagens da Antiguidade/ UFF). Membro do LHIA (Laboratório de História Antiga - UFRJ/IH). Membro do Taphos (Grupo de Pesquisa em Práticas Mortuárias no Mediterrâneo Antigo - USP). CV Lattes: http://lattes. cnpq.br/7179835505426363. 


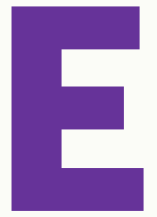

m pleno século XXI, encontramo-nos, hoje, em um momento marcado por uma infinidade de pós-episódios: um tempo pós-estruturalista, pós-processual, pósindustrial, pós-marxista, pós-positivista, pós-colonial, enfim, pós-moderno. Como Bauman (2007) alerta, há de se reconhecer a liquidez do mundo em que vivemos. Em um tempo acelerado, marcado pelo imediatismo das relações, em que tudo pode ser desconstruído e relativizado, quando a vida é condicionada por algoritmos e as relações humanas estão cada vez mais bipolarizadas e dissolvidas em um emaranhado de mídias sociais, tudo pode ser criticado, tudo pode se tornar uma polêmica, tudo pode "viralizar". No entanto, um fenômeno ainda se mantém, a grosso modo, universal e (ao menos por hora) uma condição sine qua non da realidade humana: a morte. Todos as pessoas morrem: a frase transpassa o mero slogan popularizado pelo universo fantástico criado por George R. Martin na máxima valar morghulis, mas representa uma constatação de fundo axiomático. Se há outra vida para além desta ou não, um lugar para onde as almas boas e ruins estarão destinadas, um plano espiritual marcado por estágios evolutivos, ou se a vida humana não passa de um absurdo heroico e desastroso em um universo a priori sem sentido, não há como saber.

Contudo, independentemente da fé de cada um (ou sua ausência), todos morrem(os) e é impossível negá-lo. Por outro lado, o modo como lidamos com a morte e com os mortos pode dizer mais a respeito de nós do que, muitas vezes, é possível imaginar. Nesse processo de transformação da morte biológica em morte cultural (humana) reside um rico campo de investigação histórica, antropológica e arqueológica que lida, ao mesmo tempo e de uma só vez, com alguns dos principais elementos característicos da vida social, como crenças, construção de diferenças, identidades, memórias, atributos de gênero, vínculos de afinidades entre indivíduos, ostentação de riqueza e poderes, entre outros.

Se a relação do homem com a morte é um problema comum a todas as sociedades ao longo da História da humanidade, logo, é plausivel afirmar que as práticas mortuárias como sua materialização no ato funerário - possam ser entendidas como fenômenos de grande importância para o estudo histórico de determinada população. Nesse sentido, como a Arqueologia Funerária pode auxiliar a alcançar melhor compreensão do conjunto de práticas mortuárias passadas e suas relações com a vida social? De que modo o diálogo com tal saber arqueológico pode enriquecer a História? Como tal aproximação pode ser efetuada, não apenas de um ponto de vista teórico, mas pragmático?

\section{A morte, o passado e a materialidade: alguns cuidados}

A morte e todas suas possíveis ramificações sociais já são, desde o estudo seminal de Philip Ariès (1975), tidas como campo fértil para investigações sobre o passado. Se na contemporaneidade reconhecemos uma distinção entre a morte biológica e a morte social, consequentemente é possível conceber que o morrer e todas as projeções (culturais, ideológicas, econômicas e políticas) que intrinsicamente o sucedem são, sempre, ações dotadas de historicidade. Ariès teve aí um papel fundamental. Sua análise da morte, particularmente no 
medievo, bem como seu mapeamento das diferentes atitudes e mentalidades ao longo da história das atitudes diante da morte ocupam lugar de destaque na produção historiográfica. Seus principais trabalhos a respeito do tema contam com propostas e resultados semelhantes, demonstrando por meio de seletos casos como é possível identificar cronologicamente relações distintas diante da morte em diferentes momentos da história do Ocidente (Ariès, $1975,1982,1985)$. Ariès se vale majoritariamente de documentos textuais para sua análise, traçando um olhar de longue durée. Esse será inclusive um modelo de estudo particularmente valorizado pelos historiadores franceses, como atestam as publicações sobre a morte de Edgar Morin, François Lebrun, Michelle Vovelle, Pierre Chanu, apenas para citar alguns dos mais célebres casos (Le Roy Ladurie, 1979, p. 273-84; Jacobsen, 2016, p. 3). Apesar de extremamente influente, em processo de expansão na atualidade (p. ex. Jacobsen, 2016), a obra de Ariès sofreu forte crítica necessária por um célebre sociólogo alemão: Norbert Elias.

Em texto redigido na velhice, aos 85 anos, Elias (2010) reflete a respeito da relação entre a morte, os tabus a ela associados, o desejo de pacificação e ocultamento, a tentativa de evitar ou ignorar o morrer, a mitologização do final da vida, a crença na imortalidade e, enfim, a aceitação da morte como parte da existência e os eventuais reajustes da vida diante de tal realidade iminente. Trata-se de um texto sóbrio, belamente redigido, porém sintético e de caráter quase ensaístico. Elias, no entanto, expressa profundo desagrado à obra de Ariès: ela "não explica nada", escreve ele (Elias, 2010, p. 19). Sua crítica é válida. Ele acusa Ariès de idealizar romanticamente o passado, em particular o medievo, ao considerar que os indivíduos desse período mantinham uma relação com a morte bela, serena e calma (cf. a noção de morte domesticada em Ariès, 1975). Afinal de contas, que morte pacífica é essa se, ao contrário, a vida nos estados feudais era muito mais incerta, marcada, inclusive, por episódios fatais de violência? A medicina estava significativamente limitada (se comparada aos dias atuais) e, por vezes, contribuía para a piora da condição da pessoa, ao invés de sua melhora. Analgésicos potentes não existiam e, em muitos casos, as condições higiênicas poderiam gerar mais complicações ou agonias aos enfermos e moribundos. Elias, um sociólogo, chama a atenção para um dos piores males que um historiador pode cometer nesse sentido: a romantização anacrônica do passado. Como demonstra, o erro cometido por Ariès é basear-se em tradições literárias do medievo para inferir, de modo não crítico, um conjunto de atitudes do "homem medieval" em face da morte, resultando não apenas em generalizações perigosas, mas ainda reproduzindo idealizações que pouco ou absolutamente nada estavam conectadas com a realidade de vida em determinada comunidade do medievo europeu. A bela e poética morte retratada na conduta de Isolda e o Arcebispo Turpin nos Romans de la Table Ronde não passa, pois, de um ideal da vida cortesã, uma imagem seletiva que "muitas vezes lançam mais luz no que o poeta e seu público julgavam que deveria ser, do que o que realmente era", como reforça Elias (2010, p. 19).

A História, por vezes, corre o risco de se ocupar demasiadamente do mundo das ideias, das visões, dos discursos construídos por determinados indivíduos (independentemente do quão influente eles eram em suas épocas ), das representações alegóricas e simbólicas e se esquecer de que o mundo possui uma materialidade; que determinados objetos podem definir 
ou destruir vidas, que pessoas precisam se alimentar, que dores e mazelas limitam ou mudam significativamente as vidas de seus portadores e que, em todos esses aspectos concretos da vida reside também um campo rico de projeções humanas, em que construções socioculturais as mais variadas são operacionalizadas em múltiplos níveis. Assim, a Arqueologia Funerária oferece à História uma possibilidade de renovação salutar. Ela reitera que a vida e o viver, por vezes, deixam traços que sobrevivem à morte, preservados a partir de biografias ósseas de vida ou de biografias de associações artefatuais, por exemplo (Sofaer, 2006; Giles, 2012). Ela revela que determinado ritual funerário ou certa deposição de mobiliário funerário ${ }^{1}$ não apenas serve para representar alguma condição social, mas que, ao contrário, um enterramento, por exemplo, é a própria arena na qual o social é construído: onde ocorrem negociações, tensões são operacionalizadas, hierarquias reforçadas, afiliações são (re)construídas, a memória é selecionada, laços são rompidos, a riqueza é manipulada. Assim, identidades são forjadas (Giles, 2012; para produções brasileiras conferir, por exemplo, os estudos de Sene, 2007; Souza, 2011; Silva, 2014).

A Arqueologia Funerária pode em muito contribuir ao ofício do historiador, em seu estudo sobre as práticas mortuárias do passado, de maneira a equipá-lo com as ferramentas necessárias para romper com determinados olhares unilaterais do passado e desenvolver uma visão crítica. Embora a relação entre cultura material e História venha sendo explorada há algumas décadas e, no século XXI esse suporte documental não mais constitua um tabu historiográfico (cf. Bezerra de Meneses, 1983; Funari, 2005; Barros, 2009), ainda são relativamente poucos os historiadores que demonstram interesse a respeito da materialidade dos ritos funerários e seus vestígios arqueológicos. Contudo, paradoxalmente, a historiografia contemporânea é capaz de reconhecer que a diversidade documental é salutar para o historiador (Hartog, 2013, p. 193), que é relevante ampliar o campo de estudos históricos, para não mais depender de documentos escritos como únicas formas de estudo do passado (Gruzinski, 2003, p. 7), e que historiadores não só podem como devem explorar as diferenças e contradições entre as fontes disponíveis, a fim de melhor interpretar determinados fenômenos e dotá-los de maior complexidade (Funari, 2005, p. 101).

Em seu estudo, em diversos momentos Carlo Ginzburg (1990) criticou a crença em uma espécie de realismo documental; a postura que tende a considerar nos documentos (no caso de seu estudo, textuais) a existência de uma descrição fiel da realidade, ao invés de apenas um rastro, indício ou possibilidade de exploração do contexto a partir de certa representação. De forma semelhante, Certeau (1982) chamou a atenção para a necessidade de problematizar a documentação utilizada a partir de uma perspectiva mais crítica, não encarando o documento como simples cristalização do passado mas, ao contrário, como um constructo elaborado a partir de um locus social no qual o indivíduo que produziu tal documento está inserido. Nesse sentido, portanto, não é possível um exame com um olhar inocente e não crítico (Certeau,

1 Entende-se aqui por mobiliário funerário toda sorte de bens depositados junto aos mortos. Esses artigos podem ser artefatos de tipos variados ou, ainda, também remanescentes de fauna e flora, ou determinados minérios e rochas trabalhadas, por exemplo. O que caracteriza um achado funerário como mobiliário tem está associado à intencionalidade da deposição: quando há intenção proposital de que determinado material ou objeto seja sepultado ou depositado junto ao morto. 
1982, p. 66-82).

Tais premissas teórico-metodológicas se aplicam, igualmente, à cultura material. Hays-Gilpin (2009, p. 337) já chamou a atenção para o fato de que a cultura material não reflete passivamente uma dada sociedade, mas, em sentido oposto, ela pode ser ativamente manipulada por agentes históricos na construção da realidade e de relacionamentos entre indivíduos. Assim, o entendimento da "cultura material como ativa" (Sørensen, 1991, p. 121), como propõem contribuições mais recentes da Arqueologia Pós-Processual, significa tão somente considerar que os objetos participam do processo de criação do mundo cultural. São, portanto, uma parte da dinâmica social; componentes integrados a múltiplas esferas e à vida humana. Seus significados variam de acordo com os contextos em que são constituídos e utilizados (Hodder, 1987). A cultura material, e mais especificamente, a materialidade produzida pela análise funerária, pode ser entendida como uma "entrada única em um diálogo" (Joyce, 2002, p. 142) - uma pista, um ponto de partida singular que permite evidenciar diálogos e relacionamentos estabelecidos em suas mais variadas formas e facetas. Tumbas, cremações, inumações, mobiliários funerários, entre inúmeras outras coisas, são uma plataforma e um veículo flexível, que podem ser utilizados para criar noções de tradição, manter convenções e comportamentos normativos, como, também, para romper com as mesmas normas, desafiálas e contestá-las (Parker Pearson, 2002; Sørensen, 2006, p. 105). Tal postura implica um posicionamento crítico - não somente teórico-metodológico, mas que também não deixa de ser ontológico -, que nega a existência de qualquer sentido de antemão. Ao contrário, considero que uma Arqueologia Funerária deva ser capaz de observar os objetos de estudo analisados a partir do que Sørensen (1991, p. 121) definiu como uma "fluidez de significado": destacando como grupos ou indivíduos particulares podem rejeitar ou manipular o significado de certos objetos e relacionamentos sociais, ou resistir a eles a partir de apropriações e usos diversificados (Sørensen, 1991, p. 121). Em outras palavras, implica afirmar que os objetos não possuem valores, simbologias ou significados próprios, mas que todos esses elementos são construídos a partir da prática social em contextos culturais específicos e, portanto, a referida fluidez diz respeito às múltiplas possibilidades de ações e reapropriações que podem, por vezes, estar em consonância com outras projeções maiores, mas que, em última instância, não devem ser generalizados.

Não almejo traçar aqui um histórico acerca da maneira como a cultura material começou a ser trabalhada no campo historiográfico, haja vista o estágio atual de pesquisas que abordaram o tema (Barros, 2009). Tampouco trata-se de traçar um histórico extenso sobre a Arqueologia Funerária. ${ }^{2}$ Ao contrário, meu intuito é tão somente propor uma reflexão crítica sobre diferentes contribuições advindas da Arqueologia Funerária, ao longo dos anos para o estudo das práticas mortuárias no passado, e apresentar um conjunto de sugestões sobre as

2 Empreendimento já realizado por outros autores, como Barreto, 1999, Ribeiro, 2007, Robrahn-González, 1999, Schiavetto, 2003, Silva, 2006, 2014, Souza, 2009, p.39-50, apenas para citar alguns. 
formas de desbravamento dessa perspectiva. ${ }^{3}$

\section{No princípio, era a morte: as contribuições dos estudos nos séculos XVI-XVII sobre a morte mediante a sua materialidade}

$\mathrm{Na}$ Europa, túmulos antigos consistiram em foco de interesse investigativo, desde os séculos XVI-XVII. A maior parte das escavações então realizadas em sítios funerários era motivada pelo colecionismo e por uma lógica de caça ao tesouro. As primeiras pesquisas sobre os vestígios funerários encontrados nos séculos XVI-XVII foram, portanto, conduzidas de modo muito destrutivo (no tocante à preservação dos dados e dos sítios) e, na maioria dos casos, a partir de uma ótica de saque que atendia, por um lado, a um mercado de antiguidades cada vez mais consolidado, e, por outro, às noções de erudição, nobreza e refinamento associadas às camadas mais abastadas da época.

Embora diversas conquistas intelectuais tenham sido alcançadas nesse ínterim, tal atitude "aventureiro-depredatória" perdurou em larga escala até o século XIX. Efetivamente, começou a ser modificada apenas a partir das últimas décadas do século XIX e da primeira metade do século XX. Curiosamente, como Indiana Jones e inúmeras outras produções cinematográficas atestam, esse proceder permanece fortemente associada ao ofício arqueológico no imaginário popular atual, sobretudo no caso da Arqueologia Funerária, em que tumbas e mausoléus são ainda vistos pelo senso comum como fontes de tesouros antigos.

É importante notar que, no entanto, desde o século XVI eram encontrados indícios de uso da cultura material como suporte de informação para a construção de uma narrativa histórica, por parte de alguns eruditos. Os escritos de William Camden, proeminente antiquário, historiador e topógrafo inglês oferece um exemplo nesse sentido. Em sua Britannia (1607), obra em que Camden almeja "restaurar a antiguidade à Britânia, e a Britânia a sua antiguidade", história e coreografia estão unidas, em uma narrativa que combina fontes textuais, estudos de "paisagem" e descrições de artefatos e sítios antigos. Trata-se de um dos primeiros relatórios a incluir a cultura material como objeto de investigação para o passado (Camden, 1701 [1607]). Ao longo do século XVIII, estudos subsequentes também demonstraram uma sensibilidade no tocante à catalogação de artefatos e monumentos (por vezes, funerários) como parte de um patrimônio nacional importante. Na Inglaterra, exemplos podem ser encontrados nos escritos de John Aubrey (1981 [1665-1693]), William Stukeley (1742) e Francis Grose (1783) (Trimm, 2018).

3 É importante assinalar que a própria noção contida na expressão "Arqueologia Funerária" não se traduz em uma categoria entendida em uníssono e, ainda, que tal campo possui um histórico próprio de constituição, em especial, a partir da segunda metade do séc. XX. A disciplina arqueológica tal como conhecida e concebida no século XXI não pode ser encontrada nos séculos XVI-XVII. Tal condição, por exemplo, é distinta do que se observa em relação às contribuições processuais e pós-processuais, discutidas adiante, em que tal ciência já se encontra consolidada intelectualmente e institucionalmente (Cf. item "As contribuições da Arqueologia Processual e PósProcessual, na segunda metade do séc. XX"). No entanto, valiosas contribuições intelectuais foram empreendidas entre os séculos XVI-XIX para o estudo de diferentes aspectos da morte a partir de sua materialidade, além de uma série de escavações realizadas em diversos sítios funerários. O termo "Arqueologia Funerária" é aqui empregado em referência a contextos históricos anteriores à consolidação da disciplina arqueológica moderna para se referir, portanto, a tais esforços intelectuais de estudar a morte e o passado a partir de seus vestígios materiais, não implicando, portanto, que a disciplina como hoje é conhecida já fosse então presente. 
É importante observar que, embora não houvesse, efetivamente, uma metodologia rígida de escavação ou análise dos vestígios funerários encontrados durante os séculos XVII-XVIII, esse é o momento em que grandes expedições arqueológicas são cada vez mais realizadas, a exemplo dos célebres casos de Herculano e Pompéia, escavados respectivamente em 1738 e 1748. O desejo para tal sistematização começa a se consolidar gradualmente. Em termos da Arqueologia Funerária, - ainda que a mesma não constituísse a disciplina como é conhecida na contemporaneidade, e o termo deva ser aplicado aqui com certa liberdade desde o século XVII constam formulações valiosas para seu estudo. Nesse sentido, os escritos de Gotthilf Treuer são icônicos.

Treuer (1688, apud Maner, 2018) escavou e estudou uma série de urnas funerárias na região de Brandemburgo, buscando desconstruir "falácias" populares frequentemente associadas a tais objetos: por exemplo, a crença de que elas eram feitas por anões que viviam embaixo da terra, motivo pelo qual eram conhecidas como Zwerg-Töpfe, "potes de anão" (Maner, 2018, p. 24). A partir de uma análise cuidadosa do material e de repetidas escavações, Treuer não apenas ressaltou a confecção humana de tal mobiliário funerário como identificou corretamente que tais urnas integravam um ritual de cremação antigo. Ele advogou em prol da necessidade de maior sistematização das escavações a serem realizadas, deixando, em pleno século XVII, um conjunto de instruções detalhadas para o estudo e a escavação de sítios funerários semelhantes.

Apesar de muito citado, Treuer não foi o único. Poucos anos depois, em 1719, A. Rhode trabalhou com um conjunto de tumbas pré-históricas alemães, quando redigiu, de modo equiparável a Treuer, um conjunto de instruções específicas para sua escavação. Rhode inclusive foi capaz de dividir cronologicamente os enterramentos que havia trabalhado, chamando atenção para o potencial dos vestígios funerários como matéria de investigação. Ousadamente para a época, ele chegou a declarar que tais tumbas podem informar sobre as antigas populações germânicas tanto quanto ou até mais que a própria Germânia de Tácito (Malina; Vašíček \& Zvelebil, 1990, p. 29; Maner, 2018, p. 25, 33). Esforços semelhantes de sistematização também podem ser encontrados nos escritos de Tatiščev em 1730, Mushard em 1760, e em outros autores do período (Malina; Vašíček \& Zvelebil, 1990, p. 28-29). Há, portanto, um sentimento cada vez mais recorrente de que tumbas e monumentos antigos na paisagem constituíam importante matéria-prima para o conhecimento do passado (e do presente), a ponto de a crença ter sido capturada poeticamente por um assistente de Leonard D. Hermann, posteriormente à escavação de mais de 13 mil urnas funerárias, nos seguintes versos:
Und jeder muß gestehen
daß Urnen um Gebein
E todos devem conceder
der Schlüssel aller Welt que urnas e ossos
são a chave para entender
und ihrer Sitten seyn
o mundo e os seus costumes

(Maner, 2018, p. 24)

Ainda que os séculos XVII-XVIII tenham sido cruciais para a criação e consolidação de 
sociedades de estudo, a elaboração de jornais acadêmicos e publicações voltadas à discussão em torno de tumbas e antiguidades, a realização de grandes expedições arqueológicas e, em linhas gerais, para o estabelecimento da arqueologia como método investigativo valioso de estudo sobre o passado (Henson, 2012, p. 19-25), a maioria dos debates elaborados nesse sentido, como Maner (2018, p. 24) alerta a partir dos escritos de Treuer (1688), não estavam preocupados em estudar a identidade daqueles que produziam tais artefatos ou elaborar uma reflexão mais aprofundada sobre os contextos de relações sociais no passado. Ao contrário, boa parte do interesse estava dirigido à aquisição de antiguidades valiosas, por um lado e, por outro, para uma reflexão sobre a mortalidade humana, particularmente, a partir da relação entre o homem, suas crenças religiosas e sua manifestação material. Não à toa, tumbas, cemitérios e montículos funerários eram preferidos, em detrimento de assentamentos, como locais para exame do passado: como locais cerimoniais e fontes de misteriosos 'tesouros', tais construções funcionavam como um playground de experimentação arqueológica, em consonância com as concepções e interesses da época.

Mas, até que ponto há algo a ser aproveitado nos dias atuais, da produção realizada entre os séculos XVII-XVIII para uma arqueologia funerária contemporânea? Caso não seja do interesse que se trace um histórico da disciplina arqueológica ou estudar os contextos intelectuais de época nem tampouco os desdobramentos de certos modelos historiográficosarqueológicos, será que há informações a serem extraídas desse material para o estudo de contextos funerários antigos, à luz de olhos do século XXI? Avalio que sim, apesar de serem necessárias cautelas, como deve ocorrer com todo suporte de informação, considero que alguns dados úteis - ainda que em parte lacunares - possam ser extraídos, com a possibilidade de significativo enriquecimento da compreensão sobre determinados contextos materiais. Esse é um aspecto ainda pouco explorado atualmente.

Há diversos potenciais para essa aplicação, particularmente para os estudos de visibilidade, arquitetura funerária e aqueles que estiverem interessados em entender a construção de uma paisagem ancestral, a partir da análise de contextos cemiteriais. Durante séculos, estruturas funerárias antigas contavam com grande visibilidade, sobretudo antes da Revolução Industrial, inspirando não apenas um conjunto de lendas locais, folclores e saberes a seu respeito, como a curiosidade por parte de muitos dos primeiros estudiosos e antiquários. A visibilidade de muitas estruturas na paisagem, inclusive aquelas da pré-história, inspirou não somente a emergência de mitologias regionais quanto às suas origens, como algumas eventuais expedições para sua exploração.

Abraham de la Pryme, o distinto antiquário inglês, por exemplo, registrou em seu diário, em 1699, a existência de centenas de montículos funerários em Arras, Yorkshire (Jackson \& De La Pryme, 1870, p. 200). Embora de la Pryme tenha equivocadamente pressuposto que as sepulturas eram romanas - quando se tratavam, de fato, de enterramentos bretões da Idade do Ferro -, seu relato é valioso, já que o sítio de Arras, posteriormente no século XIX, revelou tratar-se de um dos mais importantes cemitérios da Idade do Ferro para a arqueologia inglesa. Ali, centenas de inumações foram escavadas, em tumbas com mobiliário diverso, que incluíam desde adereços pessoais até carros. Hoje, em Yorkshire menos de uma dúzia de tumbas ainda 
estão visíveis em toda essa região do norte inglês: conhecemos o cemitério de Arras, sua dimensão, arranjos e configurações espaciais, apenas graças aos mapeamentos realizados por antiquários no séc. XIX, como fez William Watson e sociedades como o Yorkshire Antiquarian Club (Stead, 1965, 1979). Essa é apenas uma referência a um caso icônico e particular. No entanto, contém uma lição valiosa, do ponto de vista epistemológico: a de que há sempre algo passível de aprendizado, a partir de relatos antigos, ainda que estes sejam anteriores à formulação de determinado saber (como conhecido posteriormente) a respeito de dado objeto. Não é possível encontrar uma arqueologia funerária em de la Pryme; entretanto, nem por isso deve-se abrir mão de seus escritos, que contam com pistas ou indícios que podem deixam ser válidos.

\section{As contribuições intelectuais do século XIX e das primeiras décadas do XX}

O século XIX testemunhou um aumento exponencial de interesse pela morte, expresso não apenas pela Arqueologia, como também visível no universo da Literatura e das Artes. Embora a maioria dos estudos e das expedições durante esse período fossem desenvolvidos por "amadores" (Henson, 2012, p. 25), esses anos marcam um nível de refinamento intelectual valioso para a Arqueologia, embora frequentemente tido e descartado como etapa de mazelas intelectuais (p. ex. a visão negativa de Collis, 1997, p. 197). Certamente, alguns dos procedimentos de análises empregados por muitos estudos oitocentistas parecem estéreis, na contemporaneidade. A obsessão pela identificação e hierarquização de "raças" humanas, as inúmeras tentativas de explicação de achados arqueológicos a partir de referências bíblicas, a ótica evolucionista e simplista de interpretações, felizmente já foram abandonadas há tempos. Contudo, muitos progressos analíticos importantes foram realizados: o esforço de periodização cronológica iniciado por C. J. Thomsen (Heizer, 1962; Rowley-Conwy, 2006) ainda é seguido na atualidade. Em linhas gerais, trata-se de excelente exemplo.

Há um relevante reconhecimento de que a morte é uma força central a ser levada em consideração, e sua relação fundamental com a religião e os ritos. Talvez a principal contribuição intelectual desse período seja justamente a busca de entendimento dos nexos morte e o pensamento religioso. Por exemplo, na década de 1860, em suas Der Mensch in der Geschichte e La cité Antique, Adolf Bastian e Fustel de Coulanges, cada um a seu modo, tomam a morte como explicação primordial para a religiosidade humana, e o pensamento sobre o divino (Bartel, 1982, p. 33; Ribeiro, 2007, p. 45-46). "A morte foi o primeiro dos mistérios", escreve Foustel de Coulanges (1870, p. 19), "ela colocou o homem no caminho de outros mistérios". Ecos de uma visão semelhante são encontrados em outros estudos, como atestam os escritos de Baudrillard (1997, p. 17). Bastain e Coulanges não eram os únicos a associar a morte às origens do pensamento religioso. Para Frazer (1890), os ritos funerários surgiam como forma de controle dos vivos sobre os mortos inspirados pelo medo. Algumas décadas antes, Tylor (1871) havia defendido que a morte, como o sono, estava intrinsicamente ligada à crença em espíritos, levando-o a propor um sistema de classificação das religiões 
do mundo - entre animismo, politeísmo e monoteísmo - com base no estágio civilizatório de cada sociedade (Tylor, 1871). A antropologia e a arqueologia funerária ofereciam modelos de evolução das sociedades humanas, influenciadas pelas ideias positivistas de A. Comte e pelo evolucionismo proposto por Fergusson (Malina; Vašíček \& Zvelebil, 1990, p. 41-42), que dividia a sociedade em estágios que iam da selvageria, passavam pelo barbarismo e alcançava a civilização. Os estudos de arqueologia funerária da época são marcados por uma ótica difusionista e migracionista, focados na compreensão do surgimento e da transferência de certos rituais funerários entre grupos distintos, tomando o conjunto de rituais ligados à morte como medida do nível de evolução de determinada sociedade. A virada do século XIX e as primeiras décadas do séc. XX serão marcadas ainda pelo desdobramento de certas noções difusionistas, como os conceitos de Klem, em 1843, entre "culturas ativas/criativas" e "culturas passivas", e suas apropriações por diferentes pesquisadores, como Kossina em 1911, para o estudo de contextos arqueológicos funerários, a partir de uma ótica de transmissão cultural unilateral de uma população (supostamente) mais evoluída para uma menos evoluída (Härke, 2002, p. 157; Shaw \& Jameson, 2002, p. 185). Embora pareçam datadas, ideias do tipo - ainda que sob uma nova roupagem e sem as conotações "raciais" prévias -, foram constantemente revisitadas e reconsideradas ao longo do séc. $X X$, como é o caso da noção de celticidade acumulativa, proposta por Hawkes (1959). A ideia de um difusionismo cultural observado a partir dos registros funerários se mantém na contemporaneidade, suscitando inúmeros debates, por exemplo, nas discussões acerca das origens da prática de inumação no norte bretão durante a Idade do Ferro e sua relação com os enterramentos encontrados no norte da França durante o mesmo período (p.ex., Ramm, 1978; Stead, 1979; Halkon, 2013).

Boa parte das ideias evolucionistas, contudo, já estavam sendo postas abaixo nas primeiras décadas do século XX, em especial devido à contribuição da Escola Sociológica Francesa. Se, até então, as práticas funerárias eram amplamente tidas como indício para uma esquematização das sociedades com base em seu estado de civilização, agora observa-se uma mudança de paradigmas, que posiciona as "religiões primitivas" no mesmo patamar das "religiões complexas" das ditas sociedades civilizadas, em termos de funções e importância. "Não há, pois, no fundo, religiões que sejam falsas" , escreve Durkheim, "todas as religiões são verdadeiras à sua maneira, ainda que de maneiras diferentes, a determinadas condições de vida humana" de modo que "na verdade, não é possível dispô-las segundo ordem hierárquica" (Durkheim, 2001 [1912], p. 31).

Tal mudança radical de paradigma interpretativo, se comparada aos esquemas explicativos comumente elaborados nos séculos XVIII-XIX, se faz sentir também no modo como os mortos e os rituais fúnebres são pensados. No século XXI, talvez uma das maiores contribuições intelectuais do período seja o entendimento de que os mortos fazem parte da estrutura social. Apesar da importância seminal de Durkheim, são as publicações de Hertz (2004 [1907]) e, particularmente, de Van Gennep (2013 [1909]) que irão causar expressivo impacto no estudo de diversos contextos funerários. Ambos autores exploram um conjunto de dicotomias entre sagrado e profano construído em torno da morte, evidenciando como tais noções não são absolutas, mas, ao contrário, resultam de distintos processos sequenciais. A visão de Van 
Gennep a respeito dos rituais funerários como ritos de passagem se mostrou particularmente influente e é amplamente utilizada na atualidade, não apenas pela Arqueologia, como pela Sociologia e Antropologia (p.ex., Da Matta, 1977).

Ao tratar o conjunto de ritos não mais como um apêndice (p. ex. no estudo da religião), mas como objeto de investigação em si, Van Gennep (2013) identifica três estruturas rituais mais ou menos presentes em todos os casos: os ritos de separação, os de margem/transição e os ritos de agregação/reincorporação. Embora muitos citem (equivocadamente ou ao menos de modo simplista) os rituais funerários como ritos de separação por excelência, o autor ressalta que os três estágios estão presentes nos rituais associados à morte. Por vezes, são os ritos de margem aqueles com maior duração ou complexidade, os de agregação os mais elaborados e aos quais, frequentemente, é atribuída maior importância em cerimônias funerárias (Van Gennep, 2013, p. 128). Grande parte das contribuições intelectuais desenvolvidas nas três primeiras décadas do séc. XX só foi incorporada de fato à Arqueologia nas décadas de 60-70, quando uma parcela dessas obras foi reimpressa (p.ex., a publicação no Brasil do estudo de Van Gennep pela editora Vozes, na década de 70). Esse é um fenômeno verdadeiro, não apenas para as produções iniciais em língua francesa (como os estudos de Hertz e Van Gennep), como também em língua inglesa (como no caso de Radcliffe-Brown, 1922), quando ocorreu o que foi nomeado de "atraso de paradigma" (Metcalf \& Huntington, 1991, p. 14-15; Ribeiro, 2007, p. 59). Apesar desse atraso, ecos da publicação de Van Gennep, por exemplo, são sentidos em diferentes momentos, em influentes investigações arqueológicas da segunda metade do séc. $X X$, fazendo-se presentes não apenas na escola processual norte-americana como nas obras de autores da arqueologia marxista e soviética (Alekshin, 1983, p. 137).

\section{As contribuições da Arqueologia Processual e Pós-Processual, na segunda metade do séc. XX}

As contribuições tidas como mais relevantes na atualidade, para o estudo das materialidades associadas à morte são frutos de debates ocorridos na segunda metade do século XX. A chamada "New Archaeology" ou o Processualismo surgiu nos EUA, em meados da década de 1960, a partir da aproximação entre a Antropologia e a Arqueologia, defendendo um modelo de arqueologia eminentemente antropológico, que teve como um de seus principais expositores Lewis Binford (Binford, 1962; 1971; Binford \& Binford, 1968). ${ }^{4}$ Em linhas gerais, os princípios e conceitos básicos do Processualismo na Arqueologia podem ser resumidos da seguinte forma: 1) o desenvolvimento de um caráter científico; 2) a natureza da arqueologia

\footnotetext{
4 Destacam-se também as produções de David Clarke, que divulgou alguns conceitos da New Archaeology na Inglaterra. Clarke explicitou a importância de englobamento, pela Arqueologia, de abordagens multidisciplinares em suas análises, desenvolvendo e aplicando novos métodos de trabalho. À época, foi um dos principais divulgadores do uso de técnicas quantitativas no ofício arqueológico (Robrahn-González, 1999, p. 20).
} 
passa a ser explanatória; 3) desenvolvem-se análises sobre os processos culturais, ${ }^{5}$ 4) 0 processo de estudo voltado à formulação de hipóteses a serem testadas; 5) a adoção da Teoria Geral dos Sistemas como procedimento básico para a identificação e caracterização de padrões culturais; 6) o desenvolvimento de pesquisas a partir de questões específicas, não mais avolumando dados obtidos aleatoriamente em campo; 7) o desenvolvimento de uma perspectiva ecossistêmica, privilegiando a relação entre cultura e meio ambiente; 8) o rigor metodológico de amostragens e a adoção de testes estatísticos, a fim de permitir a elaboração de generalizações (Robrahn-González, 1999, p. 20-21).

Neste período, alguns importantes cuidados teórico-metodológicos são levantados em discussão mais ampla, o que pode ser ilustrado pela contribuição de Ucko (1969). O autor buscou chamar a atenção para os cuidados críticos, na interpretação de registros arqueológicos funerários à luz de relatos etnográficos. Ele foi um dos primeiros a defender a noção de que mudanças ou transformações ocorridas na esfera das práticas mortuárias não correspondem automaticamente a alterações em crenças religiosas (Ucko, 1969, p. 263-265). ${ }^{6}$

No âmbito dos estudos mortuários destaca-se a publicação editada por Brown (1971), Approaches to the Social Dimensions of Mortuary Practices, que constituiu uma pedra pilar para os estudos de aspectos mortuários ao longo de décadas. Dentre os textos reunidos no volume, o de Binford (1971), em especial, foi bem recebido e citado como leitura obrigatória ou importante referencial para pesquisas subsequentes ao longo de décadas, ainda que o próprio autor o considerasse apenas um ponto de partida e, curiosamente, como Chapman (2003, p. 308) destacou, jamais tenha voltado a escrever outro texto a respeito dessa temática, em toda sua carreira.

Binford (1971) buscou chamar a atenção para o potencial do estudo das práticas mortuárias, incorporando certas contribuições, como as de Hertz (1907) e Van Gennep (1908), expandindo-as criticamente, além de explorar e desenvolver os distintos conceitos formulados por Radcliff-Brown (1922) e Goodenough (1963), para entender o papel desempenhado pela persona social do morto. ${ }^{7}$ De certo modo, Binford (1971) propõe um renovar da perspectiva evolucionista, pois considera que em sociedades cada vez mais complexas haveria uma infinidade de papeis sociais a serem desempenhados; logo, nesses casos seria possivel observar uma maior variabilidade de práticas mortuárias. O autor destaca que, quanto maiores as relações sociais características de pessoas de camadas sociais altas, maior o envolvimento e dedicação no tratamento concedido ao corpo (Binford, 1971, p. 9-15). Em suas palavras, a heterogeneidade

5 Destaca-se, em especial, o surgimento de análises pautadas em um estudo de culturas cruzadas (Cross-Cultural studies). O estudo transcultural pode ser feito de duas formas: a primeira, conhecida como abordagem Californiana, busca comparar dados obtidos a partir de culturas de diferentes regiões, em uma área maior e entrecruzar e comparar esses dados de forma estatística, a fim de agrupar culturas semelhantes (Mcnett, 1979, p. 39). A segunda forma, conhecida como holística, é caracterizada como um "método para testar empiricamente as teorias que tentam explicar algumas características da existência humana. O método dimensiona variáveis teóricas em uma extensa amostra de culturas espalhadas mundialmente e examina as correlações estatísticas entre essas variáveis para determinar se as relações intervariáveis são previstas pela teoria" (Narrol et all, 1974, p. 121, apud Mcnett, 1979, p. 39-40). Conferir Tainter (1978, p. 122-126) para perspectivas de estudos transculturais associados ao estudo de práticas mortuárias.

6 Ribeiro (2007, p. 72) destaca que Ucko (1969) teria também inaugurado a análise comparativa na Arqueologia das Práticas Mortuárias.

7 A primeira parte do texto busca ainda mapear e elaborar uma crítica a certas produções, como as de Tylor, Frazer e Kroeber, desconstruindo boa parte dos argumentos e princípios elaborados por esses autores (Binford, 1971, p. 6-7). 
de tratamentos funerários, que "é característica de uma única unidade sociocultural, pode variar diretamente de acordo com a complexidade da hierarquia de status, como também de acordo com a complexidade em geral da organização de uma sociedade de acordo com unidades de pertencimento e outras formas de solidariedade" (Binford, 1971, p. 13). Binford (1971), entretanto, jamais analisou quaisquer vestígios materiais arqueológicos, baseando-se exclusivamente em relatos etnográficos, para desenvolver ideias generalizantes passíveis de aplicação posterior a estudos arqueológicos de práticas mortuárias, a partir de contextos específicos (Chapman, 2003, p. 306) - tarefa assumida por outros autores, como Peebles (1971), Saxe (1971) e Larson (1971), com textos publicados na mesma edição de Approaches to the Social Dimensions of Mortuary Practice. Saxe, em particular, desempenhou papel fundamental para a divulgação de uma perspectiva processual para o estudo da arqueologia funerária. Sua tese de doutorado foi amplamente referida, embora ela não tenha sido publicada.

Em linhas gerais, a maior contribuição deste período é a possibilidade de pensar, a partir do estudo do que ficou conhecido como persona social do morto, a existência de variações no tratamento dos mortos em uma mesma sociedade e o entendimento de que a arqueologia funerária pode informar acerca da vida social. ${ }^{8}$ Em termos intelectuais ou historiográficos, a variabilidade de tratamentos funerários não deve mais ser considerada como fruto de ideias difusionistas ou migracionais (a partir de contatos com diferentes culturas), nem tampouco como resultado de transformações religiosas. Trata-se de um reflexo das próprias variações, entre as personae que compõem determinada sociedade; um reflexo da pluralidade de relações e papeis sociais. De certa forma, as práticas mortuárias deixam de ser tidas somente em associação com indivíduos, passando a ser compreendidas como representações de "personalidades" vinculadas a comportamentos e papeis sociais específicos (Lull, 2000, p. 577). Assim, Peebles (1971), em seu estudo sobre o sítio arqueológico de Moundville (Alabama, EUA), argumentou que indivíduos tratados diferentemente em vida seriam também tratados de maneira diferenciada após sua morte (constatação que, hoje, sabemos ser falsa). É, portanto, a partir desse contexto de produções que surge a noção de que "os mortos falariam sobre os vivos, gerando a possibilidade de reconstruir a organização social dos vivos, baseada nos status sociais deduzidos do contexto funerário" (Ribeiro, 2007, p. 74).

Andrew Fleming (1973), ao investigar inúmeras tumbas nas Ilhas Britânicas, que datam do Neolítico à Idade do Bronze inicial (do quarto milênio ao começo do primeiro milênio a.C.), verificou que se os enterramentos forem considerados como projetos, como ação social planejada, como construções socioculturais, é possível concluir que somente uma de suas funções é abrigar o morto. Os enterramentos também visariam o estabelecimento de uma relação e a transmissão de uma mensagem ao espectador vivo, integrando um sistema sinalizador, elaborado para manter uma determinada organização ou coesão social (Fleming, 1973, p. 189-190).

É preciso destacar que o final da década de 1970 e início dos anos 1980 foram

8 A persona social do morto corresponderia a uma seleção de representações de identidades e memórias a respeito do morto, feitas pelos vivos a partir de determinados papeis e funções sociais. Pode-se dizer que essa noção da pessoa foi recuperada (e reformulada) mais recentemente por Fowler a partir da noção de "personalidade" (personhood). 
marcados por um constante crescimento de debates e de interesses em questões voltadas para aspectos culturais e, sobretudo, sociais, na Arqueologia. É nesse momento, a partir de análises de contextos históricos e de um alargamento de leituras e discussões, que o estudo de grupos subordinados passou ganhar cada vez mais peso, culminando no campo que veio a ser definido como Arqueologia Social. Em linhas gerais, esta subdisciplina arqueológica era direcionada à análise de aspectos concernentes a: 1) a divisões sociais (questões de status, grupos, posições, elites, classes, etc.); 2) a organizações sociais (Estado, sistemas de chefia, tribos, bandos, poder, parentesco) e 3) à ação e mudanças sociais (competições, difusões, guerras, migrações, trocas, etc.). Com o passar do tempo, essas áreas se expandiram, com a inclusão de novos debates e tópicos de pesquisa como, por exemplo, o estudo de questões envolvendo etnicidades, gênero e idade no tocante às divisões sociais, bem como sobre família, casa, casamento, em conexão com temas de organização social, dentre outros. Portanto, foi a partir dessa vertente que alguns dos principais estudos de hierarquizações sociais foram desenvolvidos. Foi ainda no bojo da Arqueologia Social, "filha" do Processualismo, que uma série de questionamentos e problematizações referentes à própria interpretação do passado, da materialidade e do papel do pesquisador foram levantados, vindo a culminar no que ficou conhecido como Pós-Processualismo.

Se a Arqueologia Processual, dita New Archaeology, teve o mérito de renovar os estudos das sociedades passadas, deslocando o foco de uma tradicional arqueologia descritiva (centrada no estudo de artefatos e objetos per se) para uma arqueologia explicativa (voltada para o estudo de mudanças e continuidades culturais), o Pós-Processualismo, com origens em debates de meados dos anos 1980 e principais expoentes em Hodder (1985, 1991), Shanks e Tilley (1987, 1989), representou um segundo processo de renovação, colocando em pauta o que poderia ser denominado de uma arqueologia problematizada. ${ }^{9}$ Nesse momento, as discussões e críticas formuladas cada vez mais partiam de uma perspectiva pós-moderna e colocavam em cheque o próprio modo de construção dos saberes. Uma das preocupações principais é de chamar a atenção para o fato de que artefatos arqueológicos não refletem de modo passivo uma dada realidade social: ao contrário, seus possíveis significados passam a ser encarados e interpretados como derivados de um conjunto de associações e usos que compõem "um nó de uma teia de referências e implicações" (Hodder, 1982, p. 90). A cultura material deixa de ser vista como mero reflexo passivo da realidade; o eixo de análise desloca-se, de aspectos comportamentais, ecológicos, generalizantes e sincrônicos comuns ao Processualismo, passando a contemplar o próprio agir humano em suas múltiplas possibilidades e significações:

Para os arqueólogos da Arqueologia Pós-Processual, o homem representa e dá sentido a tudo que o cerca - objetos, processos, fenômenos -, e cabe ao estudioso tentar compreender tais significados no contexto social e histórico em que ocorreram. Ora, considerando-se que o meio-ambiente é o palco da ação humana, é mais do que óbvio que a cultura material (e toda sua carga simbólica) aí está compreendida. (Ribeiro, 2007, p. 95).

9 Ou, de acordo com Hodder (1985; 1991), uma "arqueologia interpretativa". 
O Pós-Processualismo, entretanto, jamais apresentou uma única voz ou vertente ideológica, teórica, metodológica comum. Ao contrário, sua riqueza foi buscada a partir da própria diversidade e de uma perspectiva relativista do passado, agregando influências e contribuições de diferentes campos, como a hermenêutica, a fenomenologia, o póspositivismo e a filosofia da ciência (com base na filosofia antipositivista de Hegel e Kant), a teoria do agenciamento, o neomarxismo, as críticas feministas, os estudos arquitetônicos e a teoria pós-colonial, dentre outros (cf. diagrama a seguir).

Figura 1 - Campos e abordagens da arqueologia contemporânea

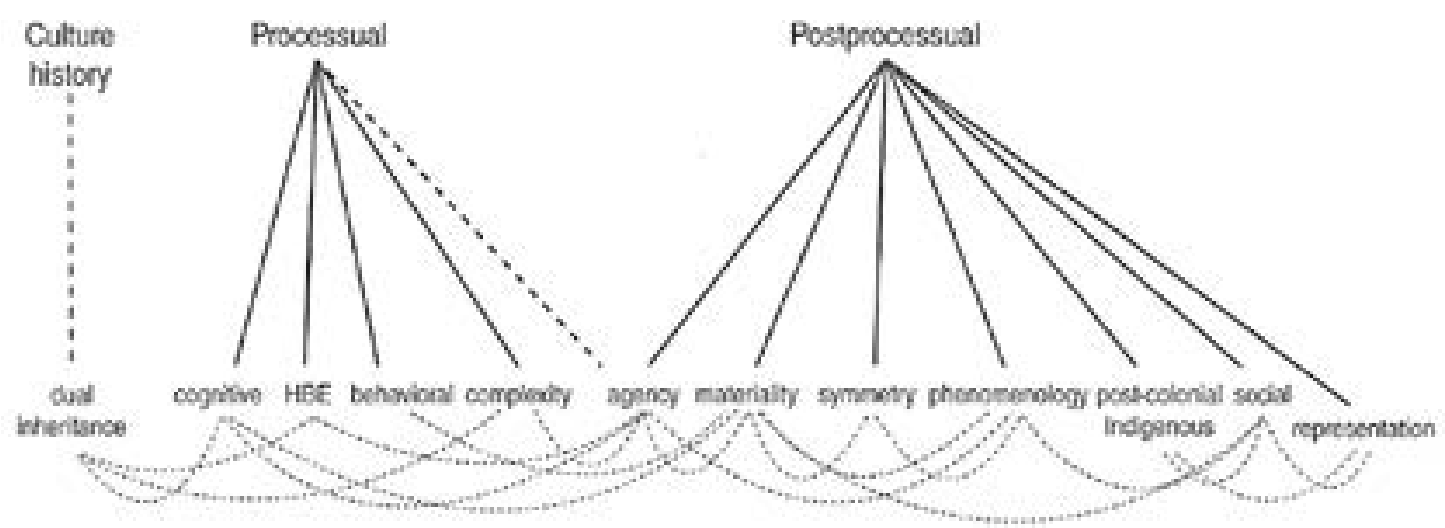

Fonte: (Hodder, 2012, p. 7)

O esquema acima busca oferecer uma síntese dos principais campos e abordagens presentes na Arqueologia contemporânea, bem como a interrelação entre essas áreas do saber. É importante observar que, embora as vertentes arqueológicas processuais e pósprocessuais tenham, cada qual à sua maneira, dado ênfase e trazido à tona determinados temas analíticos, muitos temas estão diretamente conectados. Os estudos de cognição e de ecologia evolutiva humana (HBE) caros a determinadas análises processuais será importante para o desenvolvimento do estudo do agenciamento, pilar do pós-processualismo, por exemplo. Não obstante, é possível indicar como determinadas áreas estão fortemente interconectadas, a partir de uma mesma vertente arqueológica, como é o caso dos estudos de fenomenologia, em diálogo com as noções de agenciamento, materialidade e com aquelas oriundas da arqueologia simétrica.

Embora tenha produzido múltiplos olhares e análises, o Pós-Processualismo apresenta um traço comum, que lhe é característico: sua rejeição à ideia de que o passado e os eventos humanos possam ser compreendidos em sua totalidade a partir de procederes "científicos e objetivos" (Willey \& Sabloff, 1993, p. 298). Nas palavras de Preucel e Hodder (1996):

Os principais princípios da posição interpretativa são que o passado é constituido de forma significante a partir de diferentes perspectivas, que o papel dos agentes usando ativamente a cultura material deve ser considerado, que há uma relação entre estrutura e prática, e que a 
mudança social é histórica e contingencial. (Preucel \& Hodder, 1996, p. 7).

Nesse sentido, se há algo que os estudos funerários de contextos arqueológicos (e antropológicos) diversos indicam, é que a morte (e, consequentemente, a vida social) é uma riquíssima arena, dotada de um conjunto de atitudes amplamente variantes em termos geográficos, cronológicos e culturais, de modo que é impossível a criação de grandes regras ou esquemas explicativos para seu entendimento em uníssono e em sua totalidade (Parker Pearson, 2002).

Em última instância, trata-se de uma aproximação entre História e Arqueologia, uma vez que o passado passa a ser encarado por arqueólogos como uma construção social dotada de historicidade. Ribeiro (2007, p. 127) destaca que a Arqueologia começa a se aproximar "da percepção de que, ao falar do homem, no tempo, ela faz historiografia"; a entender que sua narrativa e seus produtos são filhos de seu tempo, como já proferia Lucien Febvre (1943, p. 405), a respeito do proceder historiográfico. ${ }^{10}$

Para o estudo da Arqueologia Funerária, os anos 80-90 e início do séc. XXI, além de terem testemunhado um enriquecimento no uso de novas tecnologias e recursos para obtenção de informações, vivenciaram, ainda, um alargamento no campo de estudos a partir das chamadas Arqueologia Indígena, Arqueologia de Gênero e Arqueologia da Paisagem, dentre outros (cf. Hodder, 2012, p. 1-11; Ribeiro, 2007, p. 89-127). O Pós-Processualismo trouxe, também, para os estudos funerários, a possibilidade de pensar o conjunto de práticas mortuárias como um palco histórico, no qual disputas de poder estariam presentes, por intermédio de elementos simbólicos. Nessa perspectiva, bens funerários deixam de ser entendidos como indicadores automáticos de normas organizacionais de dado sistema social, não mais sendo considerados em função de seu valor material, mas de seu significado implícito, interpretado a partir de determinado conjunto de relações, em contextos culturais específicos. O tema das representações pode ser amplamente explorado, em especial, devido à sua potencialidade de análise, uma vez que rituais mortuários passam a ser encarados como um momento em que representações do morto, de sua família e da sociedade se apresentam. Se por um lado conflitos e tensões (étnicos, de gênero, de identidades políticas, entre grupos) são encarados a partir de vestígios funerários como as bases para dinâmicas sociais, por outro lado é negada qualquer possibilidade de dedução de padrões mortuários passíveis de classificação universal.

A incorporação ou o diálogo com a crítica neomarxista (Lull, 2000; Spriggs, 1984; cf. também Hodder \& Hutson, 2003, p. 75-89) amplia a possibilidade de entendimento do conjunto das práticas mortuárias como depósitos de labor social por parte dos vivos. Nessa perspectiva, o valor social de enterramentos seria calculado segundo o valor social de trabalho direcionado para sua realização: os gastos materiais e a energia que possibilitaram sua construção (Lull, 2000, p. 580). O neomarxismo contribuiu ainda para a Arqueologia com a preocupação de estudar as ideologias. Para a Arqueologia Funerária, buscou chamar a atenção para as maneiras

10 A citação em questão diz respeito à seguinte passagem da obra de Febvre (1943, p.405), que menciona uma ciência "que se faz e refaz continuamente: não negaria que ela se aperfeiçoa, mas não o acrescenta. Essencialmente em mudanças, tal como ele a concebe, é a obra do historiador: ela é 'filha de seu tempo'". 
como as desigualdades sociais se tornam, por vezes, visíveis em contextos funerários. Nesse sentido, a própria noção de cultura material é questionada, sendo entendida por alguns como uma máscara de ideologias, fruto de uma tradição estética e, por outro lado, de estratégias específicas de dominação (Hodder \& Hutson, 2003, p. 80-81). Eis o entendimento postulado de que "símbolos e significados culturais são usados dentro de estratégias de poder e na negociação de controle, formando também, em parte, essas próprias estratégias" (Hodder \& Hutson, 2003, p. 88). Em termos de análise mortuária é chamada a atenção, igualmente, para um aspecto, hoje, considerado fundamental (e ao mesmo tempo muito simples): o de que não necessariamente precisa haver um isomorfismo entre a condição de um indivíduo em vida e seu tratamento post mortem (Lull, 2000, p. 580).

Assim, é possível afirmar que o Pós-Processualismo trouxe consigo uma infinidade de correntes e escolas de pensamento distintas e, muitas vezes, conflitantes e autocríticas, que permitiram ampliar o horizonte de análises arqueológicas, problematizando o próprio modo como o passado é construído pelos pesquisadores. O Pós-Processualismo, no entanto, não substituiu o Processualismo: nos dias atuais ambos permanecem coexistindo e produzindo mais do que nunca. O pensamento pós-processual foi, de certa forma, responsável pelas reformulações e renovações ocorridas na década de 90 no Processualismo ${ }^{11}$, e ambas as correntes de pensamento - processual e pós-processual - sofreram críticas de um lado e de outro, reconhecendo suas próprias limitações e, ao mesmo tempo, buscando sua recriação. Hodder (2012, p. 11) não poderia estar mais correto, ao afirmar que o balanço final não deixa de ser positivo: o diálogo entre diferentes pontos de vista e posturas, por mais divergentes que sejam todas as perspectivas envolvidas, é mais enriquecedor do que a unanimidade monolítica dos estudos. Como Robrahn-González (1999, p. 23) destacou, o cenário atual de pesquisas caracteriza-se mais pela sua diversidade do que pela igualdade. Cada vez mais se caminha na direção do entendimento de que uma "sociedade é extremamente complexa e que uma teoria específica para explicar toda e qualquer sociedade não é o ideal" (Røberg, 2007, p. 104).

Os estudos das práticas mortuárias, por sua vez, testemunharam ao longo dos anos um alargamento significativo, em termos quantitativos e qualitativos. Extrapolaram a esfera do cemitério (Parker Pearson, 1993, p. 227), adquiriram novos formatos, buscaram estabelecer em seu seio um diálogo com abordagens interdisciplinares, incorporaram novas tecnologias e técnicas de trabalho. A Arqueotanatologia proposta por Duday (2009) consiste em um exemplo de tais desdobramentos intelectuais, cujos impactos podem ser sentidos não apenas na formulação de questões teóricas, mas no desenvolvimento de novos métodos interpretativos de contextos arqueológicos funerários. As contribuições recentes da Bioarqueologia e das abordagens ditas integrativas são discutidas por Camila Diogo de Souza, em artigo que compõe o atual dossiê (De Souza, 2018).

Assim, em linhas gerais, o campo de análises mortuárias, hoje, inclui diversos itens tais

11 Destaca-se, aí, o desenvolvimento da vertente chamada de "Cognitivo-Processual" (cujo maior expoente encontra-se na figura de Colin Renfrew, 1994) como resposta às críticas elaboradas pela matriz pós-processual de estudos. Em linhas gerais, a Arqueologia Cognitivo-Processual objetiva descrever como uma dada população historicamente situada conceitualizava o conteúdo de significados incorporados em diferentes domínios da cultura material (David \& Kramer, 2002, p. 21). 
como o estudo: de comportamentos mortuários (formas de deposição, tratamento e atitudes em relação ao cadáver); de acompanhamentos funerários (artefatos, ou remanescentes de fauna e flora depositados com o morto durante o funeral); da distribuição espacial de cemitérios (localização, inserção ambiental, período de uso); de mortalidades (causas de morte); de patologias e anomalias (características de doenças e traumas); de dieta e indicadores de saúde. (Silva, 2006, p. 38-39).

Esses aspectos - vinculados ao universo da "morte" e, ao mesmo tempo, integrantes da vida humana - podem, por sua vez, ser explorados e desenvolvidos a partir de múltiplos aspectos e questionamentos, interrelacionando fatores sociais, culturais, econômicos, políticos, de gênero e religiosos, dentre outros. Seu potencial de análise é tão rico e variado como a própria existência e diversidade humana. Afinal de contas, a morte é uma plataforma para construção das relações sociais (entre os vivos, e destes com seus mortos) e, pois, integra e é fundamental na vida social (Parker Pearson, 1993, p. 227).

\section{Aproximações possíveis: um guia de sugestões para como começar a trabalhar com materiais arqueológicos provenientes de contextos funerários}

Recentemente, como parte de um conjunto de atividades realizadas durante meu PósDoutorado, criei e lecionei uma disciplina intitulada "História, morte e ritos fúnebres: teoria e prática", oferecida a alunos de Mestrado e Doutorado no PPGHC-UFRJ, sob a supervisão de F. S. Lessa. O curso contava com uma aproximação entre saberes históricos e arqueológicos, para um estudo comparado da morte no passado. Após diversas leituras e intenso contato com textos de Arqueologia Funerária, uma aluna perguntou como era possível - para historiadores - trabalhar com tal suporte de informação. Sua dúvida não se centrava nas definições teóricas ou metodológicas a serem adotadas, mas, ao contrário, envolvia questões práticas. A seguir, outro aluno manifestou uma dúvida semelhante, indagando onde poderiam ser encontrados materiais para trabalho nessa direção. Constatei que as dúvidas eram compartilhadas por muitos estudantes, não apenas na pós-graduação como na graduação. Um aluno, na graduação, após a conclusão de uma aula, perguntou como eu tinha conseguido trabalhar com enterramentos no meu mestrado, se as experiências de trabalho de campo e escavações ocorreram só durante meu doutorado, no ano em que empreendi um período de Doutorado Sanduíche no exterior. Lembro-me ainda de sua reação de curiosidade na semana seguinte após a conversa, quando entreguei a ele um catálogo de escavação de um dos sítios em que havia trabalhado durante o mestrado, para que folheasse e se familiarizasse com o material. Tais dados, da ordem prática e banal para alguns, podem ser um universo desconhecido e misterioso para muitos. É possível ainda passar por uma graduação inteira - e, quem sabe, até uma pós-graduação - em História e jamais se familiarizar (em termos concretos) com a utilização de dados arqueológicos para pesquisa ou sobre as maneiras de proceder para o estudo de tais materiais. A partir dessas considerações, apresento algumas recomendações ou estratégias de estudo, bem introdutórias, sobre alguns procedimentos úteis para os que almejam desenvolver uma pesquisa com uso de 
dados da Arqueologia Funerária. Embora outras fases e ações possam ser incluídas, elenquei alguns procedimentos mais fundamentais a serem empreendidos, a partir de quatro estágios: (1) familiarização com determinado contexto histórico e identificação dos interesses de pesquisa; (2) familiarização com os materiais disponíveis na ocasião; (3) levantamento documental e coleta de dados de pesquisa; (4) criação de um banco de dados da pesquisa e de subsequentes testes e análises. A seguir são apresentados.

\section{Familiarização com o contexto e autorreconhecimento dos interesses de pesquisa}

Em primeiro lugar, é necessária uma aquisição de conhecimentos sobre o recorte (cronológico e geográfico) desejado para estudo. Para tanto, faz-se necessária uma leitura de obras de referência, grandes manuais e trabalhos seminais a respeito de determinado período e/ou região são de importância. Trata-se de uma fase inicial de exploração. Afinal, não adianta propor o estudo sobre determinada modalidade de tratamento mortuário ou a respeito de certa temática vinculada ao universo funerário, em um recorte no qual elas não existam, por exemplo. Portanto, é crucial que se adquira um conhecimento de contexto histórico mais amplo, levando-se em consideração o ambiente sociocultural e a realidade material da(s) sociedade(s) em questão. É importante observar que esse primeiro estágio serve não apenas para criar um ponto de partida sólido, reunindo informações de base valiosas, como também é um momento fundamental de autorreflexão e avaliação crítica acerca dos interesses de pesquisa de cada um. É salutar a indagação sobre a sua motivação maior de pesquisa e o que desperta seu fascínio. Em se tratando de arqueologia funerária, cabe ainda indagar se o interesse maior de investigação reside no estudo de uma área, região, grupo social ou sociedade específica, com um escopo de delimitação condicionado por fatores não funerários (p.ex., estudar a sociedade ateniense dos séculos VI-IV a.C., ou as comunidades judaicas em Amsterdam durante o séc. XVII d.C. a partir de seus ritos fúnebres) ou se, ao contrário, o objetivo reside na análise de determinada prática mortuária específica, estando a modalidade funerária intrinsecamente ligada ao recorte (p. ex., o estudo dos sambaquis costeiros em determinados sítios do litoral brasileiro) ou, ainda, se consiste em comparações a partir de recortes distintos em torno de uma mesma temática associada ao tratamento funerário (p. ex., o estudo de práticas distintas de mumificação da Antiguidade ao Medievo). Boa parte dos recortes de pesquisa pode assim ser condicionada pelos materiais disponíveis para estudo, o que conduz ao segundo ponto.

\section{Familiarização com os materiais disponíveis}

Não basta adquirir um conhecimento sólido a respeito de determinado contexto histórico, é também preciso conhecer quais materiais estão, hoje, disponíveis para seu estudo. Para tanto, faz-se necessário um entendimento do estado de conservação e preservação de 
certos achados e como eles podem ser explorados. Há uma diferença significativa em trabalhar com tumbas escavadas em meados do século XIX, e em tumbas escavadas no ano passado. Essa distinção diz respeito não apenas à quantidade de materiais disponíveis e ao seu estado, como aos limites de questões passíveis de articulação em cada caso, quando é fundamental considerar o nível de conservação, o histórico das escavações, um balanço de estudos anteriores que se debruçaram sobre o mesmo material, quais abordagens desenvolvidas até então, as condições atuais de acesso ao material e o modo como ele foi publicado (se é que o foi). A Arqueologia Funerária produz dados com naturezas distintas. Nesse sentido, também é preciso desenvolver uma familiaridade com todos. Análises osteológicas, do mobiliário funerário, da arquitetura e morfologia das tumbas, análises científicas (como estudos isotópicos ou de datações de carbono 14) constituem alguns exemplos de saberes que podem ser produzidos a partir de vestígios funerários. A aquisição de familiaridade com todos os saberes é relevante, apesar de que algumas dessas abordagens possam parecer demasiadamente técnicas para os que não contam com maior proximidade com a área, elas são extremamente valiosas para o desenvolvimento de um olhar mais completo e crítico a respeito do passado, e possibilitam levantar e testar hipóteses de modo mais efetivo, inclusive oferecendo desdobramentos para um entendimento social, que de outra maneira não seria possível.

Acrescente-se certo pragmatismo característico à pesquisa acadêmica, que deve também ser levado em consideração por aqueles que buscam uma proximidade com a Arqueologia Funerária. Nessa direção, um exemplo de cuidado concerne à escolha de materiais de pesquisa, com base nos domínios linguísticos de cada investigador. Portanto, é preciso estar atento ao fato de que, por exemplo, embora alguns relatórios de escavação sejam divulgados em línguas distintas daquela do país em que a escavação ocorre, o que por vezes facilita seu uso - como no caso de relatórios de escavações realizadas em solo grego, frequentemente redigidos em inglês e francês, devido à importância das escolas francesas, inglesas e americanas situadas em Atenas, para o estudo da Antiguidade grega. Em outros casos, a língua pode consistir em barreira. As chamadas tumbas amazonas citas das estepes eurasiáticas, onde um número considerável de sepulturas revelou itens de armamento depositados junto às mulheres, apesar de amplamente discutidas pela historiografia ocidental em língua inglesa (p.ex., Blok, 1995; Mayor, 2014) e por autores do leste europeu que, por vezes, publicam estudos de caso também nesse idioma (p.ex., Gulyaev, 2003; Simniskyte, 2007), tais tumbas foram documentadas majoritariamente em russo, lituano, ucraniano e demais línguas eslavas, dificultando o acesso a dados brutos da parte de quem não domina as línguas nas quais os catálogos de escavação foram publicados (cf. a bibliografia dos casos abordados pelos já citados Gulyaev e Simniskyte, a título de ilustração). Uma vez adquirida certa familiaridade com os materiais disponíveis, e após realizar uma avaliação sóbria das condições de pesquisa, é possível prosseguir para o próximo estágio.

\section{Levantamento documental e coleta de dados}


A coleta de dados pode adquirir diferentes facetas, segundo os temas, materiais e caminhos de pesquisa escolhidos. Por vezes pode ser árdua. O melhor modo de começar é empreender um mapeamento dos materiais almejados para estudo. Trata-se de descobrir onde eles se encontram (caso estejam preservados), como adquirir as publicações (como catálogos ou artigos que apresentem os achados em primeira mão), como obter acesso aos museus, às reservas técnicas, às instituições ou os arquivos que contenham o material ou partes dele; ou que abriguem fichas técnicas, relatórios de escavação, material antiquário, dentre outros. Diferentemente da História, na qual a relação entre o pesquisador e o objeto de estudo costuma ser, na maior parte dos casos, solitária, a Arqueologia é, por excelência, um saber colaborativo desde o trabalho de campo até a constituição intelectual, posteriormente, do objeto de estudo. O catálogo elaborado por Stead (1991) sobre as escavações de alguns cemitérios da Idade do Ferro no norte da Inglaterra é um perfeito exemplo: o relatório, que conta com trabalhos de mais de 20 especialistas em suas respectivas áreas, inclui uma apresentação de contexto, uma discussão sobre a paisagem funerária e a constituição espacial de cada um dos cemitérios escavados, uma esquematização tipológica das tumbas, uma análise do mobiliário funerário, das fibras têxteis preservadas, dos remanescentes humanos e animais, do paleoambiente, das estratigrafias, uma série de prospecções geofísicas, além de um conjunto de análises cientificas (como datações de carbono e análises de composição química de artefatos), seguidos por um mapeamento estatístico dos achados, uma discussão final do material e um apêndice detalhado que lista cada uma das tumbas escavadas, suas morfologias e conteúdo. Nem sempre, no entanto, todas essas informações são publicadas em um único catálogo, mas, ao contrário, em mídias e veículos distintos, de maneira fragmentada, cabendo ao pesquisador reuni-las. Isso, é claro, nos bem-aventurados casos, quando elas são de fato publicadas. Devido à natureza dos dados arqueológicos (e particularmente dos dados funerários), em muitos casos os resultados podem demorar anos ou décadas até que sejam publicados. Infelizmente, em inúmeras ocasiões eles sequer chegam a ser editados ou publicados formalmente.

Bancos de dados online podem ser uma importante plataforma de pesquisa nesse sentido. No Reino Unido, por exemplo, o Archaeology Data Service gerido pela Universidade de York, até 2019, já disponibilizou mais de 50 mil relatórios de escavações que nunca foram formalmente publicados (categoria de texto conhecida como "literatura cinzenta"). Agora estão ao acesso de um clique, de modo gratuito e instantâneo. Esse é apenas um exemplo desse tipo de iniciativa e, atualmente, a pesquisa online pode desempenhar um importante processo na coleta de dados científicos. Alguns museus já possuem parcelas consideráveis de seus acervos - inclusive materiais que se encontram na reserva técnica, como remanescentes humanos disponíveis para consulta online, acompanhados por relatório técnico completo, como no caso de muitos achados abrigados no Museu Britânico. Em outros casos, iniciativas como o Portable Antiques Scheme tem disponibilizado milhões (literalmente) de achados arqueológicos a partir de colaborações interinstitucionais, governamentais e voluntárias, catalogando e tornando públicos diversos artefatos, muitos oriundos de contextos funerários. Para aqueles que se encontram geograficamente na mesma região, ou ao menos no mesmo país em que seus objetos de estudo, visitas a sítios e contatos pessoais com equipes responsáveis pelo estudo ou 
a escavação de determinado sítio podem ser exemplos de atividades relativamente acessíveis, que podem gerar frutos positivos, possibilitando, por vezes, o acesso a determinados materiais, inclusive àqueles ainda não publicados. Acrescente-se que, no âmbito nacional, a biblioteca do Museu de Arqueologia e Etnografia (MAE/USP) é uma das mais importantes referências no Brasil e na América Latina para consulta de publicações arqueológicas. O agendamento de visitas para levantamento bibliográfico pode ser um exercício profícuo e uma alternativa mais acessível do que viagens de coleta ao exterior, quando estas não forem possíveis.

A aquisição de catálogos, na medida do possível, para uso pessoal por parte do pesquisador, pode agilizar significativamente a pesquisa, em alguns casos, facilitando o acesso irrestrito a determinado conjunto de dados. Editoras como a BAR (British Archaeological Reports Publishing) possuem um acervo especializado em relatórios de sítios, teses e coletâneas arqueológicas. Um número considerável de materiais desse tipo pode ser adquirido diretamente no site de muitas editoras ou por meio de plataformas como a AbeBooks e a Amazon ou, ainda, em grandes livrarias, mediante encomendas. Catálogos e relatórios de sítio, no entanto, costumam ser custosos, não apenas em decorrência de sua baixa tiragem de impressão, como também devido à existência de pranchas imagéticas, mapas e anexos que encarecem o custo de impressão gráfica. Há de se levar em consideração igualmente os gastos com as conversões monetárias (no caso de publicações importadas) e acrescentar ainda as tarifas de fretes cobradas para a entrega desses itens, que costumam ser altas (já que não são publicações leves), o que pode acarretar um valor na aquisição de um único livro dessa modalidade oscile, por exemplo, entre 300 ou 3.000 reais, de acordo com a publicação. Portanto, um levantamento extenso (seja em bancos de dados online, seja em instituições de pesquisa) pode ser sempre benéfico de antemão, a fim de reduzir custos. Em caso de recorrente dificuldade por parte do pesquisador no tocante à obtenção de acesso a determinados materiais é sempre válido reconsiderar o recorte inicial de estudo e/ou o escopo, objetivo do trabalho, de modo a adequar as ambições à realidade, ou, ao menos, traçar estratégias alternativas.

\section{Criação de banco de dados pessoal e teste de desdobramentos de pesquisa possíveis com base no material coletado}

Por fim, uma vez coletadas as informações necessárias ao desenvolvimento da pesquisa, cabe ao pesquisador organizá-las. A criação de um banco de dados que atenda às necessidades de pesquisa de cada indivíduo é recomendável. Ela permitirá que um conjunto de informações importantes sejam organizadas, condensadas, dissecadas e analisadas (em conjunto ou individualmente) a partir dos mesmos critérios, possibilitando que determinado tema seja explorado de modo mais eficiente e articulado. Para tal propósito é possível utilizar desde softwares pagos, como o FileMaker, uma plataforma de banco de dados relacional, e o Microsoft Office Access, ou até uma dúzia de outros programas gratuitos, alguns inclusive feitos por/para arqueólogos como o Archie DB. Não obstante, o Microsoft Excel é também uma alternativa bem popular entre pesquisadores $-e$, relativamente, mais familiar e de fácil conversão dos dados -, no qual é possível criar planilhas especificas que detalhem, por exemplo, 
cada uma das tumbas escavadas em um cemitério, listando-se informações técnicas variadas (como o sexo e a idade da pessoa enterrada, ou os itens de mobiliário funerário encontrados) em colunas sucessivas, para posteriormente rodar análises de perfis. Independentemente do recurso escolhido, é importante lembrar que um banco de dados deve sempre atender às necessidades de pesquisa do investigador. Sua formulação precisa, portanto, ser orientada pelas problemáticas levantadas, de modo a ordenar os dados disponíveis em categorias analíticas úteis para o teste de hipóteses. Além disso, quando realizada de modo sistemático, detalhado e minucioso, sua confecção pode, por vezes, direcionar luz a possibilidades de estudo não contempladas anteriormente.

Posso atestar a importância de tal desdobramento com base em experiência própria. Embora tenha dedicado um capítulo inteiro de minha tese de doutorado à discussão de um grupo de enterramentos infantis, posteriormente convertendo o texto em um artigo que compunha um dossiê temático sobre a arqueologia da infância organizado pela Revista da SAB (Peixoto, 2018), minha intenção original de pesquisa, à época do doutorado, jamais havia previsto levar em conta o estudo da população não-adulta. Na fase de levantamento de fontes e coleta de dados para a pesquisa, já havia notado que alguns cemitérios possuíam sepultamentos infantis, no entanto, sua proporção parecia-me efêmera na ocasião: por exemplo, se somarmos os mais de 600 enterramentos catalogados por Dent (1984) e Stead (1991), não é possível encontrar um desenho, ou fotografia sequer de uma tumba infantil. Tal ausência, no entanto, é condicionada por um descaso moderno. Ao elaborar um banco de dados dos enterramentos estudados, pude constatar que, em determinado ponto, ele já contava com mais de 50 enterramentos infantis: um número que, embora seja significantemente menor ao de inumações adultas, é, sem dúvidas, maior do que se imagina e nos oferece algumas perspectivas valiosas a respeito de um conjunto de diferenças sociais e projeções identitárias, por vezes ignorados.

Uma vez finalizado, um banco de dados oferece ao pesquisador uma possibilidade única de testar desdobramentos possíveis, tanto em níveis temáticos como teóricos. Tal como um livro, em que uma nova faceta pode emergir a cada leitura, revisitar um banco de dados, rodar novas análises, testar diferentes comparações, elencar novos agrupamentos, são exercícios úteis que podem enriquecer exponencialmente um trabalho ou, ainda, abrir caminho para pesquisas futuras. Por último, é importante lembrar que a construção de um banco de dados pode facilitar a elaboração de um catálogo de pesquisa, tópico de suma importância para trabalhos como monografias, dissertações e teses. Na Arqueologia Funerária tais catálogos podem conter descrições cemiteriais, fichamentos detalhados ou sintéticos das tumbas estudadas, róis de artefatos, detalhes a respeito dos remanescentes humanos etc. Mais do que um mero apêndice, o catálogo deve ser formulado de acordo com as propostas metodológicas do estudo, permitindo ao leitor um acesso padronizado e organizado de todo o material discutido, constituindo também parte íntegra do trabalho. Sua inclusão traduz, ainda, um valioso esforço de transparência intelectual e empoderamento do leitor, apresentando os dados sobre os quais a pesquisa se baseia, de modo a permitir que cada pessoa verifique os argumentos elaborados e chegue às suas próprias conclusões. 


\section{Considerações finais}

A Arqueologia Funerária possui amplo potencial para estudo do passado. Sua inclusão permite romper com visões idealizadas ou anacrônicas, embora, como em todos casos, cautelas e um olhar crítico devem sempre estar presentes. Tumbas são "contextos culturais complexos, envolvendo uma multiplicidade de aspectos entrelaçados", como alerta Escórpio e Gaspar (2005, p. 62) e seus potenciais de investigação e reflexão são significativos. A aproximação com saberes arqueológicos é capaz de não somente enriquecer o conhecimento a respeito dos ritos funerários, como permite explorar um conjunto de construções sociaisculturais importantes, ocorridas a partir da materialidade e manipulação dos mortos. O estudo de inumações, cremações, enterramentos, epitáfios, monumentos funerários, artefatos depositados em tumba, dentre outros, vem se desenvolvendo há séculos, tendo despertado o interesse e a curiosidade em muitos indivíduos. Nos dias atuais, as maiores contribuições para o estudo da morte a partir de sua materialidade são oriundas de debates iniciados pelo Processualismo e o Pós-Processualismo, sobretudo a níveis teóricos e metodológicos, embora análises anteriores, como as formuladas no séc. XIX, por exemplo, ocupem ainda um lugar (merecidamente) de importância, presente em muitos casos relevantes. Há de se reconhecer que, embora alguns autores sejam frequentemente descartados por suas visões de mundo, hoje consideradas "datadas", a leitura de suas obras pode ser útil, muito além de um mero exercício de revisão historiográfica, oferecendo pistas complementares a respeito de determinadas configurações físicas quando estas ainda estavam mais bem preservadas ou visíveis na paisagem, por exemplo. Estudos recentes, por sua vez, fornecem um conjunto de dados valiosos, lançando luz sobre aspectos não apenas relacionados à morte e aos ritos funerários, como acerca da vida social que, de outra forma, seriam impossivieis de serem contemplados, como a recorrência de traumas e patologias, associações interpessoais póstumas, e relações entre pessoas e objetos com bases em marcadores identitários específicos, citando alguns casos. Atém disso, a diversidade de materiais produzidos por sítios diferentes significa que diferentes estratégias, recortes temáticos e leituras podem ser articuladas com base na documentação disponível: por exemplo, em tumbas onde se observa a deposição de fauna junto aos mortos, uma aproximação com a zooarqueologia pode se mostrar profícua, enriquecendo de maneira exponencial o entendimento a respeito do contexto analisado. $O$ caráter aglutinador e colaborativo da Arqueologia Funerária, somado aos progressos científicos recentes e o refinamento de análises laboratoriais físico-químicas (como as isotópicas, por exemplo), oferecem um panorama animador para os anos que estão por vir. Seja como for, hoje, tanto a História quando a Arqueologia estão cientes de que os mortos não podem se enterrar e que, dada tal impossibilidade, um riquíssimo campo de pesquisas se abre. O poema Necrológio Severino, redigido por Affonso Romano de Sant'Anna é uma trágica (ou cômica) e sensível observação, servindo aqui como valioso lembrete para todos:

Necrológio Severino 


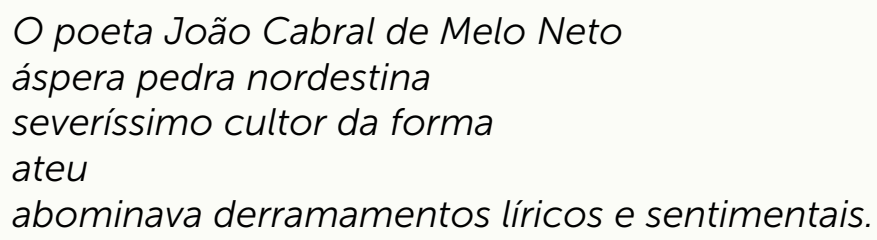

Não obstante isto, era acadêmico.

Não obstante isto, era diplomata.

Não obstante isto, morreu rezando

e seu corpo

foi velado no Salão dos Poetas Românticos. (Sant'Anna, 2005, p. 93).

\section{Referências Bibliográficas}

ALEKSHIN, Vadim A. et all. Burial Customs as an Archaeological Source [and Comments]. Current Anthropology. Chicago, v. 24, n. 2, p. 137-149, 1983.

ARIĖS, Philippe. Western attitudes toward death: from the middle ages to the present. Baltimore: John Hopkins Univ. Press, 1975. 111p.

ARIĖS, Philippe. The hour of our death. New York: Vintage Books, 1982. 651p.

ARIÈS, Philippe. Images of man and death. Cambridge, Mass: Harvard University Press, 1985. $217 p$.

AUBREY, John. Monumenta Britannica: Or a Miscellany of British Antiquities. 2 volumes. Boston: Little Brown \& Company, 1981. 1143p.

BARRETO, Cristiana. Arqueologia Brasileira: Uma perspectiva histórica e comparada. Revista do MAE, 3, 201-2012, 1999.

BARROS, José D'Assunção. História da Cultura Material: Notas sobre um campo histórico em suas relações intradisciplinares e interdisciplinares. PatrimoniUSS. Vassouras, p. 1-17, n. 1, jul. 2009.

BARTEL, Brad. A historical review of ethnological and archaeological analyses of mortuary practice. Journal of Anthropological Archaeology. S/l, v. 1, n. 1, p. 32-58, mar. 1982.

BAUDRILLARD, Jean. A Troca Simbólica e a Morte. Lisboa: Edições 70, 1997. 295p.

BAUMAN, Zygmunt. Modernidade líquida. Rio de Janeiro: Jorge Zahar, 2007. 258p.

BEZERRA DE MENESES, Ulpiano. A cultura material no estudo das sociedades antigas. Revista de História, v. 115, p. 103-117, 1983.

BINFORD, Lewis. Archaeology as Anthropology. American Antiquity. Washington, v. 28, n. 2, p. 217-25, 1962. 
BINFORD, Lewis. Mortuary Practices: Their Study and Their Potential. In: BROWN, James A. (Ed.). Approaches to the Social Dimensions of Mortuary Practices: Memoirs of the Society for American Archaeology. Washington D.C.: Society for American Archaeology, p. 58-67, 1971.

BINFORD, Sally R. \& BINFORD, Lewis. New Perspectives in Archaeology. Chicago: Aldine Publishing Company, 1968. 373p.

BLOK, Josine. The early Amazons: modern and ancient perspectives on a persistent myth. Leiden; New York: E.J. Brill, 1995. 473p.

BROWN, James A. (Ed.). Approaches to the Social Dimensions of Mortuary Practices. Washington D.C.: Society for American Archaeology, 1971. 112p.

CAMDEN, William. Britannia. Camden's Britannia Abridg'd: With Improvements, and Continuations, to this Present Time. To which are Added, Exact Lists of the Present Nobility of England, Scotland, and Ireland. London: J. B. Printer, 1701. 103p.

CERTEAU, Michel de. A escrita da história. Rio de Janeiro: Forense Universitária, 1982. 384p.

CHAPMAN, Robert. Death, society and archaeology: The social dimensions of mortuary practices. Mortality. S/l, v. 8, n. 3, p. 305-312, ago. 2003.

COLLIS, John. Celtic myths. Antiquity. Cambridge, v. 71, n. 271, p. 195-201, mar. 1997.

DA MATTA, Roberto. O carnaval como um rito de passagem (Ensaios de Antropologia Estrutural). Petrópolis: Vozes, 1977. 173p.

DAVID, Nicholas e KRAMER, Carol. Teorizando a etnoarqueologia e a analogia. Horizontes antropológicos. Porto Alegre, v. 8, n. 18, p. 13-60, 2002.

DENT, John Strickland. Wetwang Slack: an Iron Age cemetery on the Yorkshire Wolds. Thesis (Master of Philosophy). Department of Philosophy, University of Sheffield, Sheffield, 1984. 199p.

DUDAY, Henri. The archaeology of the dead: lectures in archeothanatology. Oxford: Oakville, CT: Oxbow Books; David Brown Book Co, 2009. 230p.

DURKHEIM, Émile. As formas elementares de vida religiosa: o sistema totêmico na Austrália. São Paulo: Paulus, 2001. 536p.

ELIAS, Norbert. A solidão dos moribundos: seguido de envelhecer e morrer. Rio de Janeiro: Jorge Zahar, 2010. 107p.

ESCÓRPIO, Elaine; GASPAR, Maria Dulce. Indicadores de diferenciação social e de gênero dos pescadores-coletores que ocuparam a Reigão dos Lagos - RJ. Cadernos do LEPARQ, v. II, 3, p. 47-65, 2005.

FEBVRE, Lucien. Le problème de l'incroyance au XVle siècle: la religion de Rabelais. Paris: Michel, 1943. 579p.

FLEMING, Andrew. Tombs for the Living. Man. London, v. 8, n. 2, p. 177-193, jun. 1973.

FRAZER, James G. The Golden Bough: A Study in Magic and Religion. 2 vol. London: Macmilan 
and co., 1890. 848p.

FUNARI, Pedro Paulo. Os historiadores e a cultura material. In: PINSKY, Carla Bassanezi. (Org.). Fontes Históricas. São Paulo: Contexto, p. 81-109, 2005.

FUSTEL DE COULANGES, Numa Denis. La cité antique: Étude sur le culte, le droit, les instituitions de la Grèce et de Rome. Paris: L. Hachette et. cie., 1870. 496p.

GILES, Melanie. A forged glamour: landscape, identity and material culture in the Iron Age. Bollington: Windgather, 2012. 224p.

GINZBURG, Carlo. Mitos, emblemas, sinais: morfologia e história. São Paulo: Companhia das Letras, 1990. 288p.

GOODENOUGH, Ward Hunt. Cooperation in Change: an Anthropological Approach to Community Development. London: Russel \& Russel, 1963. 543p.

GROSE, Francis. The Antiquities of England and Wales. Volume 1. London: S. Hooper, 1783.172p.

GRUZINSKI, Serge. A colonização do imaginário: sociedades indígenas e ocidentalização no México espanhol. Séculos XVI-XVIII. São Paulo: Companhia das Letras, 2003. 488p.

GULYAEV, Valeriy Ivanovich. Amazons in the Scythia: New Finds at the Middle Don, Southern Russia. World Archaeology. London, v. 35, n. 1, p. 112-125, 2003.

HALKON, Peter. The Parisi: Britons and Romans in East Yorkshire. Stroud: The History Press, 2013. 304p.

HÄRKE, Heinrich. (Ed.). Archaeology, ideology and society: the German experience. Frankfurt am Main: Lang, 2002. 438p.

HARTOG, François. Regimes de historicidade: presentismo e experiências do tempo. Belo Horizonte: Autêntica, 2013. 272p.

HAWKES, Christopher. The ABC of the British Iron Age. Antiquity. Cambridge, v. 33, n. 131, p. 170-182, sep. 1959.

HAYS-GILPIN, Kelley Ann. Gender. In: BENTLEY, R. Alexander; MASCHNER, Herbert D. G. \& CHIPPINDALE, Christopher. (Eds.). Handbook of Archaeological Theories. Lanham: Altamira Press, p. 335-349, 2009.

HEIZER, Robert F. The Background of Thomsen's Three-Age System. Technology and Culture. Baltimore, v. 3, n. 3, p. 259, 1962.

HENSON, Donald. Doing archaeology: a subject guide for students. London; New York: Routledge, 2012. 236p.

HERTZ, Robert. Death and the right hand. London: Routledge, 2004. 180p.

HODDER, Ian (Ed.). Symbolic and Structural Archaeology. Cambridge: Cambridge University Press, 1982. 200p. 
HODDER, Ian. Postprocessual Archaeology. In: SCHIFFER, Michael Brian. (Ed.). Advances in Archaeological Method and Theory. New York: Academic Press, p. 1-26, 1985.

HODDER, Ian. The contextual analysis of symbolic meanings. In: (Ed.). The Archaeology of Contextual Meanings. Cambridge: Cambridge University Press, p. 1-10, 1987.

HODDER, lan. Postprocessual archaeology and the current debate. In: PREUCEL, Robert. (Ed.). Processual and Post processual archaeologies: multiple ways of knowing the past. Carbondale: Southern Illinois University Press, p. 30-41, 1991.

HODDER, Ian (Ed.). Archaeological theory today. 2nd ed. Cambridge, UK; Malden, MA: Polity Press, 2012. 347p.

HODDER, lan \& HUTSON, Scott. Reading the past: current approaches to interpretation in archaeology. 3rd ed. Cambridge, UK; New York: Cambridge University Press, 2003. 308p.

JACKSON, Charles. \& DE LA PRYME, Abraham. The Diary of Abraham de la Pryme, the Yorkshire Antiquarian. Durham: Sturtees Society; Andrew \& Co., 1870. 347p.

JACOBSEN, Michael Hviid. "Spectacular Death" - Proposing a New Fifth Phase to Philippe Ariès's Admirable History of Death. Humanities. Basel, v. 5, n. 19, p. 1-20, 2016.

JOYCE, Rosemary A. The languages of archaeology: dialogue, narrative, and writing. Oxford; Malden, MA: Blackwell, 2002. 186p.

LARSON, Lewis H. Archaeological Implications of Social Stratification at Etowah site, Georgia. In: BROWN, James A. (Ed.). Approaches to the Social Dimensions of Mortuary Practices. Washington D.C.: Society for American Archaeology, p. 58-67, 1971.

LE ROY LADURIE, Emmanuel. The territory of the historian. Hassocks: Harvester Press, 1979. $345 p$.

LULL, Vicente. Death and society: a Marxist approach. Antiquity. Cambridge, v. 74, n. 285, p. $576-580$, set. 2000.

MALINA, Jaroslav; VAŠíČEK, Zdeněk \& ZVELEBIL, Mark. Archaeology yesterday and today: the development of archaeology in the sciences and humanities. Cambridge, UK; New York: Cambridge University Press, 1990. 336p.

MANER, Brent. Germany's ancient pasts: archaeology and historical interpretation since 1700. Chicago: The University of Chicago Press, 2018. 336p.

MAYOR, Adrienne. The Amazons: lives and legends of warrior women across the ancient world. Princeton: Princeton University Press, 2014. 544p.

MCNETT, Charles W. Junior. The Cross-Cultural Method in Archaeology. In: SCHIFFER, Michael Brian. (Ed.). Advances in Archaeological Method and Theory. Volume 2. New York: Academic Press, p. 39-76, 1979.

METCALF, Peter. \& HUNTINGTON, Richard. Celebrations of death: the anthropology of mortuary ritual. 2nd ed. Cambridge: Cambridge University Press, 1991. 258p. 
PARKER PEARSON, Mike. The Powerful Dead: Archaeological Relationships between the Living and the Dead. Cambridge Archaeological Journal. Cambridge, v. 3, n. 2, p. 203-229, 1993.

PARKER PEARSON, Mike. The archaeology of death and burial. College Station, TX: Texas A \& M Univ. Press, 2002. 250p.

PEEBLES, Christopher. S. Moundville and Surrounding Sites: Some Structural Considerations of Mortuary Practices. In: BROWN, James A. (Ed.). Approaches to the Social Dimensions of Mortuary Practices. Washington D.C.: Society for American Archaeology, p. 68-91, 1971.

PEIXOTO, Pedro Vieira da Silva. Quando a morte vem cedo: espaço, mobiliário e performance fúnebre em enterramentos infantis da Idade do Ferro nas Ilhas Britânicas. Revista da Sociedade de Arqueologia Brasileira. Online, v. 31, n. 2, p. 210-238, 2018.

PREUCEL, Robert. W. \& HODDER, lan. (Eds). Contemporary archaeology in theory: the new pragmatism. Chichester, UK; Malden, Mass: Wiley-Blackwell, 1996. 637p.

RADCLIFFE-BROWN, Alfred Reginald. The Andaman Islanders. Cambridge: Cambridge University Press, 1922. 512p.

RAMM, Herman G. The Parisi. London: Duckworth, 1978. 160p.

RENFREW, Colin. Towards a cognitive archaeology. In: RENFREW, Colin \& ZUBROW, Ezra B. W. (Eds.). The ancient mind: Elements of cognitive archaeology. Cambridge: Cambridge University Press, p. 3-12, 1994.

RIBEIRO, Marily Simões. Arqueologia das práticas mortuárias: uma abordagem historiográfica. São Paulo (SP): Alameda, 2007. 194p.

RØBERG, Frank. Arqueologia Escandinava: da Pré-História aos Vikings. Entrevista realizada por Johnni Langer. Brathair. São Luís, v. 7, n. 1, p. 104-106, 2007.

ROBRAHN-GONZÁLEZ, Erika Marion. Arqueologia em Perspectiva: 150 anos de prática e reflexão no estudo de nosso passado. Revista USP. São Paulo, v. 44, p. 9-31, 1999.

ROWLEY-CONWY, Peter. The concept of prehistory and the invention of the terms 'prehistoric' and 'prehistorian': the Scandinavian origin, 1833-1850. European Journal of Archaeology. Cambridge, v. 9, n. 1, p. 103-130, 2006.

SANT'ANNA, Affonso Romano de. Vestígios. Rio de Janeiro, RJ: Rocco, 2005. 197p.

SAXE, Arthur A. Social Dimensions of Mortuary Practices in a Mesolithic Population from Wadi Halfa, Sudan. In: BROWN, James A. (Ed.). Approaches to the Social Dimensions of Mortuary Practices. Washington D.C.: Society for American Archaeology, p. 39-57, 1971.

SCHIAVETTO, Solange Nunes de Oliveira. A arqueologia guarani: construção e desconstrução da identidade indígena. São Paulo: Anablume, 2003. 138p.

SENE, Gláucia Aparecida Malerba. Indicadores de gênero na pré-história brasileira: contexto funerário, simbolismo e diferenciação social - O sítio arqueológico Gruta do Gentio II, Unaí, Minas Gerais. Tese (Doutorado em Arqueologia). Museu de Arqueologia e Etnologia, Universidade de São Paulo, São Paulo, 2007. 389p. 
SHANKS, Michael \& TILLEY, Christopher. Re-constructing archaeology: theory and practice. Cambridge: Cambridge University Press, 1987. 267p.

SHANKS, Michael \& TILLEY, Christopher. Archaeology into the 1990s. Norwegian Archaeological Review. S/l, v. 22, p. 1-12, 1989.

SHAW, Ian \& JAMESON, Robert. Dictionary of Archaeology. London: John Wiley \& Sons, 2002. $736 \mathrm{p}$.

SILVA, Sérgio Francisco Serafim Monteiro da. Terminologias e classificações usadas para descrever sepultamentos humanos: exemplos e sugestões. Revista do Museu de Arqueologia e Etnologia. São Paulo, n. 15-16, p. 113, 2006.

SILVA, Sérgio Francisco Serafim Monteiro da. Arqueologia Funerária: corpo, cultura e sociedade. Ensaios sobre a interdisciplinaridade no estudo das práticas mortuárias. Recife: Editora Universitária da UFPE, 2014. 138p.

SIMNIŠKYTĖ, Andra. Weapons in Iron Age Women's. Archaeologia Baltica. Klaipéda, v. 8, p. 283-291, 2007.

SOFAER, Joanna R. The body as material culture: a theoretical osteoarchaeology. Cambridge, UK; New York: Cambridge University Press, 2006. 188p.

SØRENSEN, Marie. The construction of gender through appearance. In: WALDE, Dale \& WILLOWS, Noreen D. (Eds.). The archaeology of gender: proceedings of the Twenty-second Annual Conference of the Archaeological Association of the University of Calgary. Calgary: University of Calgary Archaeological Association, p. 121-129, 1991.

SØRENSEN, Marie. Gender, things and material culture. In: NELSON, Sarah M. (Ed.). Handbook of gender in archaeology. Oxford: Altamira Press, p. 105-136, 2006.

SOUZA, Camila Diogo de. Práticas Mortuárias na Região da Argólida entre os séculos XI e VIII a.C. Revista do Museu de Arqueologia e Etnologia. São Paulo, Suplemento 13, p. 85-94, 2009.

SOUZA, Camila Diogo de. A morte lhe cai bem. Reconsiderando o significado do mobiliário funerário na construção do prestígio social. Revista M. Estudos sobre a morte, os mortos e o morrer. Rio de Janeiro, vol. 3, n. 6, jun.-dez., 2018.

SPRIGGS, Matthew. Marxist perspectives in archaeology. Cambridge: Cambridge University Press, 1984. 158p.

STEAD, Ian Mathieson. The La Tène cultures of eastern Yorkshire. York: Yorkshire Philosophical Society, 1965. 135p.

STEAD, Ian Mathieson. The Arras culture. York: Yorkshire Philosophical Society, 1979. 123p.

STEAD, Ian Mathieson. Iron Age cemeteries in East Yorkshire: excavations at Burton Fleming, Rudston, Garton-on-the-Wolds, and Kirkburn. London: British Museum Press; 1991. 237 p.

STUKELEY, William. Paleographia Britannica: Or Discourses on Antiquities in Britain. London: R. Manby, 1742. 52p. 
TAINTER, Joseph A. Mortuary Practices and the Study of Prehistoric Social Systems. In: SCHIFFER, Michael Brian. (Ed.). Advances in Archaeological Method and Theory. Volume 1. New York: Academic Press, p. 105-141, 1978.

TRIMM, Ryan. Heritage and the legacy of the past in contemporary Britain. London; New York: Routledge, 2018. 350p.

TYLOR, Edward Burnett. Primitive Culture. London: John Murray, 1871. 426p.

UCKO, Peter J. Ethnography and archaeological interpretation of funerary remains. World Archaeology. London, v. 1, n. 2, p. 262-280, out. 1969.

VAN GENNEP, Arnold. Os ritos de passagem. Petrópolis: Vozes, 2013. 168p.

WILLEY, Gordon R. \& SABLOFF, Jeremy A. A history of American archaeology. 3rd ed. New York: W.H. Freeman, 1993. 384p.

Recebido em: 30 de outubro de 2018

Aprovado em: 2 de dezembro de 2018 